\title{
Penerapan Lesson Study Untuk Meningkatkan Self-Concept Mahasiswa Pada Mata Kuliah Konsep Dasar Matematika
}

\author{
Detty Syefriyani ${ }^{1}$, Saleh Haji ${ }^{2}$ \\ S2 Pendidikan Matematika, Universitas Bengkulu, syefriyanidetty@gmail.com ${ }^{1}$, salehhaji@unib.ac.id²
}

\section{INFO ARTIKEL}

Riwayat Artikel:

Diterima: 23-03-2018

Disetujui: 12-04-2018

\section{Kata Kunci:}

Lesson Study

Self Concept

ABSTRAK

Abstrak: Tujuan penelitian ini adalah untuk meningkatkan self concept melalui penerapan lesson study bagi mahasiswa calon guru pada mata kuliah konsep dasar matematika semester satu pendidikan sekolah dasar di STKIP-PGRI Lubuklinggau. Jenis penelitian ini merupakan penelitian deskriptif kualitatif. Subjek penelitian ini adalah 38 mahasiswa program studi pendidikan sekolah dasar STKIP-PGRI Lubuklinggau. Penelitian ini dilaksanakan dalam bentuk rangkaian kegiatan lesson study yang terdiri dari 3 tahapan yaitu perencanaan, pelaksanaan, dan refleksi. Teknik pengumpulan data yang digunakan dalam penelitian ini adalah dengan teknik interview/wawancara, observasi, dokumentasi, dan angket. Persentase rata-rata pertemuan adalah $16,25 \%$.
\end{abstract}

\begin{abstract}
The main purpose of this research is to raise self concept through lesson study for college student of teacher training on elementary school basic concept mathematics 1st semester at STKIP-PGRI Lubuklinggau. The method of this research is descriptive qualitative. The subject of the research is 38 college student of STKIP-PGRI Lubuklinggau. The research consist of 3 steps, which are planning, implementation, and reflection. This research using interview, observation, documentation and quessioner technics. The average percentage of self-concept overall from 1st meeting to the 4nd meeting is $16,25 \%$.
\end{abstract}

\section{A. LATAR BELAKANG}

Pendidikan pada dasarnya adalah proses komunikasi yang di dalamnya mengandung transformasi pengetahuan, nilai-nilai dan keterampilan-keterampilan, di dalam dan di luar sekolah yang berlangsung sepanjang hayat (life long process), dari generasi ke generasi dan pendidikan sangat bermakna bagi kehidupan individu, masyarakat, dan suatu bangsa [1]. Berdasarkan hasil observasi peneliti pada mahasiswa semester satu pendidikan sekolah dasar STKIP-PGRI Lubuklinggau, terlihat bahwa mahasiswa cenderung kurang aktif saat melangsungkan pembelajaran. Hal ini terbukti saat dosen mengajukan pertanyaan kepada mahasiswa dan mahasiswa harus dirangsang terlebih dahulu untuk dapat menjawab pertanyaan dari dosen tersebut. Mahasiswa pun masih terlihat malu-malu untuk mengungkapkan apa yang ada di dalam pikirkan mereka.

Kita sudah semestinya mengupayakan berbagai alternatif dan inovasi dalam rangka meningkatkan kemampuan matematika siswa kita [5]. Salah satu kuncinya adalah perbaikan proses pembelajaran, khususnya dengan meningkatkan porsi menalar, memecahkan masalah, berargumen dan berkomunikasi, melalui materi ajar yang lebih kontekstual atau realistik. Berbicara mengenai kemampuan matematis, saat peneliti melakukan observasi pada mahasiswa calon guru pendidikan sekolah dasar semester satu di STKIP-PGRI Lubuklinggau, terlihat bahwa mahasiswa masih kesulitan menangkap apa yang dikomunikasikan oleh dosen hal ini terbukti saat dosen memberikan soal kepada mahasiswa untuk dikerjakan didepan kelas, mahasiswa secara berulang ulang menanyakan maksud dari soal tersebut.

Mahasiswa pada dasarnya mengerti apa yang dimaksudkan oleh dosennya tersebut, akan tetapi mahasiswa kurang mampu menuliskan jawaban dengan bahasa sendiri, kurang mampu menggungkapkan kembali suatu uraian matematika dalam bahasa sendiri, kurang mampu memberikan penjelasan secara tertulis atas jawaban yang diberikan. Hal ini membuktikan bahwa self concept mahasiswa masih tergolong rendah. Self concept merupakan landasan untuk dapat menyesuaikan diri dan terbentuk karena proses umpan balik dari individu yang lain. self concept bukan merupakan faktor yang dibawa sejak lahir melainkan gambaran campuran yang diperoleh atas penilaian terhadap 
diri sendiri dan pandangan yang diberikan oleh orang lain [6]. Adapun indikator dari self concept adalah: Memiliki

kemampuan mengenali/mengidentifikasi diri sendiri, contoh penyataannya "Saya merasa sulit mengerjakan tugastugas yang berkaitan dengan matematika". Memiliki pandangan atau pengharapan mengenai gambaran diri yang ideal di masa depan, contoh pernyataannya "Saya merasa mampu mengerjakan soal-soal matematika diluar contoh yang ada". Memiliki penilaian terhadap diri sendiri dalam hal pencapaian pengharapan, contoh pernyataannya "setiap ujian berlangsung, saya yakin atas jawaban saya". Memiliki standar kehidupan yang sesuai dengan dirinya, contoh penyataannya "Dalam ujian matematika, saya merasa mampu mengerjakan tanpa bantuan dari orang lain".[4]

Suatu model pembinaan guru untuk mencapai kualitas pembelajaran adalah lesson study. Lesson study adalah model pembinaan profesi pendidik melalui pengkajian pembelajaran secara kolaboratif dan berkelanjutan berlandaskan prinsip-prinsip kolegalitas dan mutual learning untuk membangun komunitas belajar [2]. Lesson study adalah bentuk kegiatan yang dilakukan oleh seorang guru/sekelompok guru yang bekerja sama dengan orang lain (dosen, guru) dalam merancang kegiatan untuk meningkatkan mutu belajar siswa dan pembelajaran yang dilakukan oleh seorang guru dari perencanaan pembelajaran yang dirancang bersama/sendiri, kemudian diobservasi oleh teman guru yang lain san setelah itu melakukan refleksi bersama atas hasil pengamatan yang baru saja dilakukan [3]. Maka dari itu, peneliti ingin menerapkan lesson study pada perguruan tinggi guna dapat meningkatkan self concept mahasiswa terhadap mata kuliah konsep dasar khususnya. Berdasarkan latar belakang masalah yang diuraikan di atas, maka rumusan masalah dalam penelitian ini adalah bagaimana meningkatkan self concept melalui penerapan lesson study bagi mahasiswa calon guru pada mata kuliah konsep dasar matematika semester satu pendidikan sekolah dasar di STKIP-PGRI Lubuklinggau?

Tujuan penelitian untuk mengetahui peningkatan self concept melalui penerapan lesson study bagi mahasiswa calon guru pada mata kuliah konsep dasar matematika semester satu pendidikan sekolah dasar di STKIP-PGRI Lubuklinggau.

\section{B. METODE PENELITIAN}

Jenis penelitian ini merupakan penelitian deskriptif kualitatif. Penelitian kualitatif berusaha mengungkapkan gejala secara menyeluruh dan sesuai dengan konteks (holistic contextual) melalui pengumpulan dari latar alami dengan memanfaatkan peneliti sebagai instrumen kunci. Dengan tujuan mendeskripsikan penerapan dan manfaat lesson study terhadap kemampuan self concept mahasiswa dimata kuliah konsep dasar matematika. Subjek penelitian ini adalah 38 mahasiswa program studi pendidikan sekolah dasar STKIP-PGRI Lubuklinggau semester 1 dan tim lesson study mata kuliah konsep dasar matematika.

Penelitian ini di laksanakan dalam bentuk rangkaian kegiatan lesson study yang terdiri dari 3 tahapan yaitu perencanaan, pelaksanaan, dan refleksi seperti terlihat pada gambar 1 berikut ini :

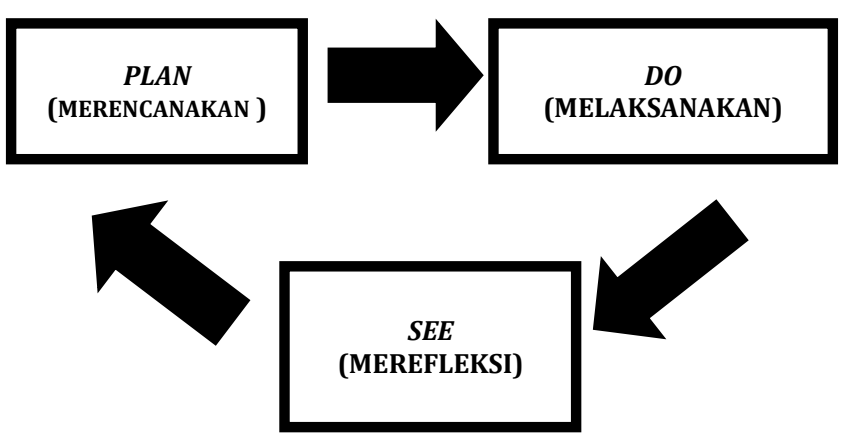

Gambar 1. Langkah-langkah Lesson Study

Teknik pengumpulan data yang digunakan dalam penelitian ini adalah dengan teknik interview/wawancara, observasi, dokumentasi, dan angket.

\section{HASIL DAN PEMBAHASAN}

\section{Perencanaan Sebelum diterapkan Lesson Study}

Sebelum dilaksanakan Lesson Study terlebih dahulu tim Lesson Study melakukan observasi kelas untuk mengetahui bagaimana pembelajaran mata kuliah Konsep Dasar Matematika berlangsung dan Bagaimana self concept mereka terhadap pembelajaran. Observasi dilakukan dua kali yaitu pada hari selasa tanggal 29 September 2017 dan 03 Oktober 2017, sedangkan waktu pelaksanaan Lesson Study dimulai pada tanggal 24 Oktober 2017 sampai tanggal 14 November 2017. Lesson Study dilaksanakan pada hari Selasa pukul 15.45 - 18.00 selama 4 kali pertemuan. Dalam setiap pertemuan ada 1 dosen model yang mengisi pembelajaran, sedangkan 2 dosen model lainnya sebagai observer. Selanjutnya, sebelum pelaksanaan pembelajaran, ada beberapa hal yang perlu dipersiapkan agar dapat tampil secara maksimal, antara lain:

\section{a) Pembagian Materi}

Pada hari selasa tanggal 03 Oktober 2017 setelah tim lesson study melakukan observasi pembelajaran di kelas dan menemui dosen pengampu mata kuliah Konsep Dasar Metematika maka dilakukan pembagian materi terkait materi yang akan diajarkan dalam Lesson Study yaitu materi persamaan linier, pertidaksamaan linier, persamaan kuadrat, dan pertidaksamaan kuadrat. 


\section{b) Membuat Perangkat Pembelajaran}

Perangkat pembelajaran dibuat melalui dua tahap. Tahap pertama, perangkat pembelajaran dibuat sebelum pelaksanaan koordinasi materi dan model pembelajaran dengan tim Lesson Study, sehingga dosen model sudah memiliki bahan apa yang akan didiskusikan. Perangkat pembelajaran ini terdiri atas: RPP, powerpoint, KUIS) (yang tertuang dalam powerpoint), angket, dan Lembar Observasi. Tahap kedua, perangkat pembelajaran yang sudah dibuat pada tahap I diperbaiki setelah pelaksanaan peer teaching, sehingga dosen model dapat mengantisipasi kemungkinan-kemungkinan yang akan terjadi dalam pembelajaran nanti berdasarkan hasil peer teaching. Perangkat pembelajaran ini terdiri atas: RPP KUIS (yang tertuang dalam powerpoint), powerpoint, angket, dan Lembar Observasi.

\section{c) Membuat Perencanaan Terkait Koordinasi Materi dan Model pembelajaran yang akan digunakan}

Sebelum pelaksanaan Lesson Study, dosen model berkoordinasi dengan tim Lesson Study untuk membahas materi yang akan diajarkan dengan tujuan dosen model menguasai sepenuhnya materi yang akan diajarkan. Selain itu dosen model juga membahas model pembelajaran yang akan diterapkan dalam pelaksanaan pembelajaran di kelas nantinya. Pembahasan ini bertujuan agar dosen model mendapat saran dan masukan dari anggota tim Lesson Study lainnya yang sudah mengajar terlebih dahulu di kelas. Pemilihan model pembelajaran juga berdasarkan hasil observasi ketika dosen model lain mengajar.

Model pembelajaran yang digunakan yaitu, pada pertemuan pertama menggunakan metode ceramah; pertemuan kedua menggunakan model Kooperatif tipe two stay two stray (TSTS); pertemuan ketiga menggunakan metode Ekspositori, diskusi kelompok, tanya jawab, kombinasi induktif dan deduktif, dan pemberian tugas; pertemuan keempat Ekspositori, diskusi kelompok, tanya jawab, kombinasi induktif dan deduktif, dan pemberian tugas yang sudah dimodifikasi sendiri.

\section{d) Konsultasi ke Dosen Pengampu Mata Kuliah Konsep Dasar Matematika}

Perangkat perkuliahan yang telah dibuat oleh tim Lesson Study kemudian dikonsultasikan kepada dosen pengampu mata kuliah Konsep Dasar Matematika. Karena perkuliahan dilaksanakan pada hari Selasa konsultasi ini dilaksanakan dua hari sebelumnya yaitu hari Sabtu, sehingga ketika pembelajaran di kelas dosen model benarbenar menguasai materi yang akan disampaikan. Penguasaan materi sangat berpengaruh terhadap rasa percaya diri dosen model, sehingga manajemen kelas benar-benar dapat terkontrol dengan baik dan self concept pada mahasiswa dapat meningkat.

\section{Pertemuan Pertama Pelaksanaan} Pembelajaran Lesson Study

\section{a) Perencanaan (Plan)}

Model pembelajaran yang digunakan pada pertemuan pertama yaitu menggunakan metode ceramah. Setelah itu dosen menyiapkan perangkat pembelajaran berdasarkan model/metode yang telah dipilih dan sesuai dengan materi yang akan diajarkan selanjutnya. pelaksanaan Lesson Study pertemuan pertama dimulai pada tanggal 24 Oktober 2017. Lesson Study dilaksanakan pada hari Selasa pukul 15.45 18.00. Dalam setiap pertemuan ada 1 dosen model yang mengisi pembelajaran, sedangkan 2 dosen model lainnya sebagai observer.

Dalam pelaksanaan pembelajaran di kelas, dosen model selalu datang lebih awal dengan tujuan dapat mempersiapkan pembelajaran dengan baik. Pembelajaran dimulai pada pukul 15.45 dan diakhiri pada pukul 18.00. Pembelajaran dilaksanakan di ruang 14. Mata kuliah yang diajarkan adalah Konsep Dasar Matematika untuk mahasiswa Pendidikan Sekolah Dasar semester 1. Dalam setiap kali pelaksanaan selalu terdapat satu dosen model yang mengajar dan ada 2 orang yang menjadi observer. Dalam pembelajaran dosen model menggunakan perlengkapan diantaranya LCD proyektor, laptop, dan spidol.

\section{b) Pelaksanaan (Do)}

Materi yang diajarkan pada pertemuan pertama ini adalah Persamaan Linier. Dalam pelaksanaannya mahasiswa sudah dalam keadaan siap untuk memulai pembelajaran dengan membawa buku mereka masingmasing. Dalam pembelajaran dosen model menggunakan metode ceramah dan diselingi dengan tanya jawab antara dosen dengan mahasiswa. Karena mahasiswa dalam kelas ini merupakan mahasiswa pilihan sehingga pembelajaran yang dilakukan berjalan lancar tanpa kendala yang berarti. Mayoritas mahasiswa tergolong aktif dalam mengikuti pembelajaran tetapi ada satu mahasiswa yang terlihat paling aktif dan sangat 
menonjol daripada teman yang lainnya. Dalam pelaksanaan pembelajaran ada mahasiswa asyik bermain handphone, dan mengobrol dengan teman sehingga terlihat tidak memperhatikan penjelasan dosen. Untuk mengatasi masalah tersebut dosen model mencoba memberikan permasalahan kepada mahasiswa sehingga dapat memberikan dorongan mahasiswa yang kurang memperhatikan pembelajaran agar kembali memperhatikan penjelasan dari dosen.

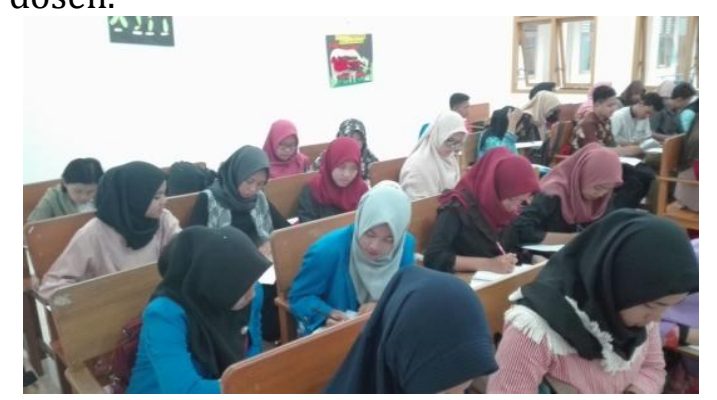

Gambar 2. Pelaksanaan Lesson Study Pertemuan Pertama

Hasil pada pertemuan pertama, Mayoritas mahasiswa tergolong aktif dalam mengikuti pembelajaran tetapi ada satu mahasiswa yang terlihat paling aktif dan sangat menonjol daripada teman yang lainnya. Dalam pelaksanaan pembelajaran ada mahasiswa asyik bermain handphone, dan mengobrol dengan teman sehingga terlihat tidak memperhatikan penjelasan dosen. Untuk mengatasi masalah tersebut dosen model mencoba memberikan permasalahan kepada mahasiswa sehingga dapat memberikan dorongan mahasiswa yang kurang memperhatikan pembelajaran agar kembali memperhatikan penjelasan dari dosen. Ini ditunjukkan juga pada hasil angket self concept yang mereka isi. Pada pertemuan pertama presentase self concept sebesar $67,96 \%$ dan pertemuan pertama rata-rata nilai kuis yang dilakukan sebesar 73,76. Hal ini ditunjukkan dari hasil presentase rata-rata angket dan kuis yang dilakukan self concept mahasiswa terhadap materi persamaan linier masih sangat kecil.

\section{c) Refleksi (see)}

1) Langkah-langkah pembelajaran dalam Rencana Pelaksanaan Pembelajaran (RPP) dalam harus mencerminkan sintaks model/metode pembelajaran yang digunakan karena pada pertemuan pertama dengan menggunakan metode ceramah ternyata siswa masih pasif pada saat diskusi dikelas dan pembelajaran masih berpusat pada dosen..

2) Mengerjakan terlebih dahulu tugas atau soal latihan yang akan diberikan kepada mahasiswa, sehingga dapat mengukur kesiapan, self concept mahasiswa dan menambah kepercayaan diri kita sebagai dosen model dihadapan mahasiswa.

3) Pada pertemuan pertama presentase self concept sebesar 67,96\% dan pertemuan pertama rata-rata nilai kuis yang dilakukan sebesar 73,76. Hal ini ditunjukkan dari hasil presentase rata-rata angket dan kuis yang dilakukan self concept mahasiswa terhadap materi persamaan linier masih sangat kecil. Untuk indikator pertama dari self concept sudah terlihat mahasiswa sudah memiliki kemampuan mengenali/mengidentifikasi diri sendiri, berdasarkan angket yang mereka isi diakhir pembelajaran.

4) Memberi tugas terkait materi yang akan dipelajari. Hal ini bertujuan agar pada saat pembelajaran di kelas nantinya mahasiswa sudah membaca materi yang akan diajarkan sehingga sudah siap mengikuti pelajaran.

\section{Pertemuan Kedua Pelaksanaan Pembelajaran Lesson Study \\ a) Perencanaan (Plan)}

Berdasarkan hasil refleksi pada pertemuan pertama maka perencanaan yang akan dilakukan dipertemuan kedua ini adalah memperbaiki langkah-langkah pembelajaran yang akan diterapkan untuk dapat meningkatkan self concept mahasiswa karena pada pertemuan pertama dengan menggunakan metode ceramah ternyata siswa masih pasif pada saat diskusi dikelas dan pembelajaran masih berpusat pada dosen sehingga self concept mahasiswa masih kurang terlihat. Model pembelajaran yang digunakan pada pertemuan kedua yaitu menggunakan model kooperatif tipe two stay two stray (TSTS), diharapkan dapat meningkatkan self concept mahasiswa. Setelah itu dosen menyiapkan perangkat pembelajaran berdasarkan model yang telah dipilih dan sesuai dengan materi yang akan diajarkan selanjutnya. Waktu pelaksanaan Lesson Study pertemuan kedua dimulai pada tanggal 31 oktober 2017. Lesson Study dilaksanakan pada hari Selasa pukul 15.45 18.00 . 


\section{b) Pelaksanaan (do)}

Materi yang diajarkan pada pertemuan kedua ini adalah Pertidaksamaan Linier. Dalam pelaksanaannya mahasiswa sudah dalam keadaan siap untuk memulai pembelajaran dengan membawa buku mereka masing-masing. Dalam pembelajaran dosen model menggunakan model Kooperatif tipe two stay two stray (TSTS) dan diselingi dengan tanya jawab antara dosen dengan mahasiswa. Karena mahasiswa dalam kelas ini merupakan mahasiswa pilihan sehingga pembelajaran yang dilakukan berjalan lancar tanpa kendala yang berarti. Mayoritas mahasiswa tergolong aktif dalam mengikuti pembelajaran tetapi masih ada mahasiswa yang terlihat paling aktif dan sangat menonjol dari pada teman yang lainnya. Untuk mengatasi masalah tersebut dosen model mencoba memberikan permasalahan kepada mahasiswa sehingga dapat memberikan dorongan mahasiswa yang masih belum bisa aktif dalam pembelajaran.

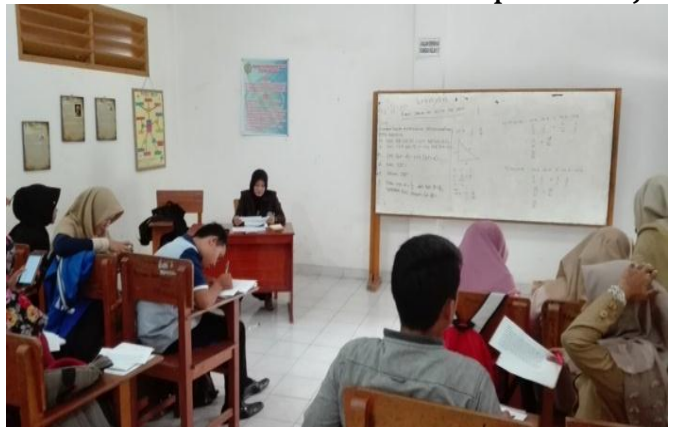

Gambar 3. Pelaksanaan Lesson Study Pertemuan Kedua

Hasil pada pertemuan kedua dalam pelaksanaannya mahasiswa sudah dalam keadaan siap untuk memulai pembelajaran dengan membawa buku mereka masingmasing. Dalam pembelajaran dosen model menggunakan model kooperatif tipe two stay two stray (TSTS) dan diselingi dengan tanya jawab antara dosen dengan mahasiswa. Karena mahasiswa dalam kelas ini merupakan mahasiswa pilihan sehingga pembelajaran yang dilakukan berjalan lancar tanpa kendala yang berarti. Mayoritas mahasiswa tergolong aktif dalam mengikuti pembelajaran tetapi masih ada mahasiswa yang terlihat paling aktif dan sangat menonjol dari pada teman yang lainnya. Untuk mengatasi masalah tersebut dosen model mencoba memberikan permasalahan kepada mahasiswa sehingga dapat memberikan dorongan mahasiswa yang masih belum bisa aktif dalam pembelajaran. Ini ditunjukkan juga pada hasil angket self concept yang mereka isi. Pada pertemuan kedua presentase self concept sebesar $70,67 \%$ dan pertemuan kedua rata-rata nilai kuis yang dilakukan sebesar 74,47.

\section{c) Refleksi (See)}

1) Penyampaian materi dengan menggunakan bahasa yang baku dengan menggunakan bahasa Indonesia agar lebih jelas.

2) Pemilihan model pembelajaran harus disesuaikan dengan kondisi/karakter karena mahasiswa membuat siswa lainnya agak santai dan kurang mengikuti instruksi permainan.

3) Mahasiswa terlibat aktif dalam pembelajaran dikelas.

4) Dalam setiap pembelajaran yang akan dilaksanakan, sebaiknya direncanakan suatu pembelajaran yang berbeda dengan pembelajaran sebelumnya agar mahasiswa tidak merasa bosan dengan tetap menggunakan metode pembelajaran yang mampu mengaktifkan mahasiswa.

5) Presentase self concept mahasiswa pada pertemuan kedua sebesar 70,67\% dan pertemuan kedua rata-rata nilai kuis yang dilakukan sebesar 74,47. Untuk indikator pertama dari self concept sudah terlihat mahasiswa sudah memiliki kemampuan mengenali/mengidentifikasi diri sendiri, sedangkan untuk indikator yang kedua yaitu memiliki pandangan atau pengharapan mengenali gambaran diri yang ideal di masa depan sudah meningkat berdasarkan angket yang mereka isi diakhir pembelajaran.

\section{Pertemuan Ketiga Pelaksanaan Pembelajaran Lesson Study a) Perencanaan (Plan)}

Berdasarkan pelaksanaan dan refleksi pertemuan kedua penerapan pembelajaran lesson study untuk meningkatan self concept sudah terlihat dengan menggunakan model Kooperatif tipe two stay two stray (TSTS) namun masih belum tercapainya untuk indikator ketiga dan keempat. Sehingga tim merencanakan kembali metode pembelajaran yang akan dilaksanakan yang menurut tim dapat meningkatkan self concept yang dapat dilihat dari tercapainya keseluruhan indikator. Metode yang akan digunakan pada pertemuan ketiga yaitu ekspositori, diskusi kelompok, tanya jawab, kombinasi induktif dan deduktif, dan 
pemberian tugas untuk materi persamaan kuadrat. Waktu pelaksanaan Lesson Study pertemuan ketiga pada tanggal 7 November 2017. Lesson Study dilaksanakan pada hari Selasa pukul 15.45 - 18.00 dengan materi pertidaksamaan kuadrat.

\section{b) Pelaksanaan (Do)}

Materi yang diajarkan pada pertemuan pertama ini adalah persamaan kuadrat. Dalam pelaksanaannya mahasiswa sudah dalam keadaan siap untuk memulai pembelajaran dengan membawa buku mereka masing-masing. Dalam pembelajaran dosen model menggunakan metode Ekspositori, diskusi kelompok, tanya jawab, kombinasi induktif dan deduktif, dan diselingi dengan tanya jawab antara dosen dengan mahasiswa diakhir diskusi dan pemberian tugas. Dalam pembelajaran ini penerapan metode ini berjalan dengan baik, lebih aktif dan self concept mahasiswa sudah mulai terlihat peningkatannya.

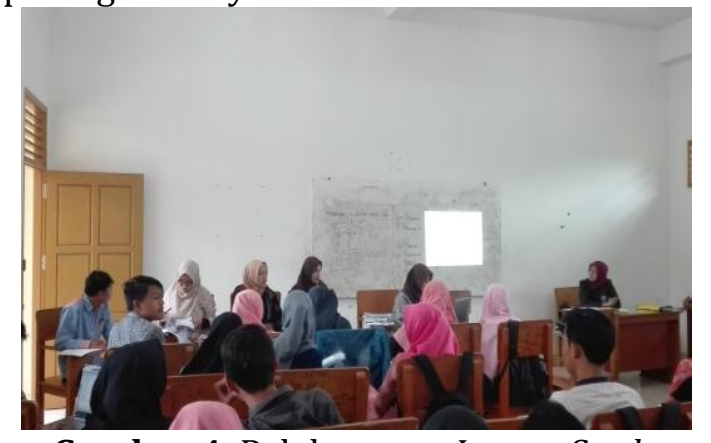

Gambar 4. Pelaksanaan Lesson Study Pertemuan Ketiga

Hasil pertemuan ketiga, dosen membuka perkuliahan dengan menyapa mahasiswa dan mengecek kehadiran. Alasannya karena pada minggu sebelumnya saat melakukan observasi sudah diperkenalkan oleh dosen mata kuliah konsep dasar matematika dan diberi kesempatan untuk memperkenalkan diri. Setelah membuka pembelajaran dosen meberikan motivasi dan penguatan kepada mahasiswa calon guru, agar melatih mahasiswa calon guru untuk menjadi guru yang profesional. Kemudian dosen membagikan LKM dan menampilkan media pembelajaran berupa power point dan menyajikan contoh-contoh konkret dalam kehidupan sehari-hari. Mahasiswa memperhatikan bahan yang disajikan oleh dosen. Untuk mengatasi masalah tersebut dosen model mencoba memberikan permasalahan kepada mahasiswa sehingga dapat memberikan dorongan mahasiswa yang masih belum bisa aktif dalam pembelajaran. Ini ditunjukkan juga pada hasil angket self concept yang mereka isi. Pada pertemuan ketiga presentase self concept sebesar $81,85 \%$ dan pertemuan ketiga rata-rata nilai kuis yang dilakukan sebesar 77,73.

\section{c) Refleksi (see)}

1) Mahasiswa terlibat aktif dalam pembelajaran dikelas.

2) Dalam pembelajaran ini penerapan metode ini berjalan dengan baik, lebih aktif dan self concept mahasiswa sudah mulai terlihat peningkatannya dari pertemuan kedua dan ketiga presentase nya sebesar $81,85 \%$ dan pertemuan ketiga rata-rata nilai kuis yang dilakukan sebesar 77,73. Walaupun masih ada beberapa mahasiswa yang masih kurang aktif, tetapi ternyata semua pencapaian indikator dari self concept sudah tercapai secara keseluruhan. dibuktikan dengan hasil angket yang telah diisi dan dibantu dengan hasil kuis mahasiswa yang dilakukan diakhir pertemuan dengan materi pertidaksamaan kuadrat.

\section{Pertemuan Keempat Pelaksanaan Pembelajaran Lesson Study \\ a) Perencanaan (Plan)}

Pada perencanaan di pertemuan keempat tim ingin mereview kembali metode pembelajaran yang digunakan pada pertemuan ketiga adapun metode yang akan review ulang yaitu metode ekspositori, diskusi kelompok, tanya jawab, kombinasi induktif dan deduktif, dan diselingi dengan tanya jawab antara dosen dengan mahasiswa diakhir diskusi dan pemberian tugas. Waktu pelaksanaan Lesson Study pertemuan keempat pada tanggal 14 November 2017. Lesson Study dilaksanakan pada hari Selasa pukul 15.45 - 18.00 dengan materi pertidaksamaan kuadrat.

\section{b) Pelaksanaan (Do)}

Materi yang diajarkan pada pertemuan pertama ini adalah pertidaksamaan kuadrat. Dalam pelaksanaannya mahasiswa sudah dalam keadaan siap untuk memulai pembelajaran dengan membawa buku mereka masing-masing. Dalam pembelajaran dosen model menggunakan metode Ekspositori, diskusi kelompok, tanya jawab, kombinasi induktif dan deduktif, dan diselingi dengan tanya jawab antara dosen dengan mahasiswa diakhir diskusi dan pemberian tugas. Dalam pembelajaran ini penerapan metode ini berjalan dengan baik dan lebih aktif 
pembelajaran yang dilakukan berjalan lancar tanpa kendala yang berarti. Mayoritas mahasiswa tergolong aktif dan self concept mahasiswa sudah terlihat ketika mereka mengemukakan ide yang ada dan dalam mengikuti pembelajaran tidak ada yang menonjol daripada teman yang lainnya.

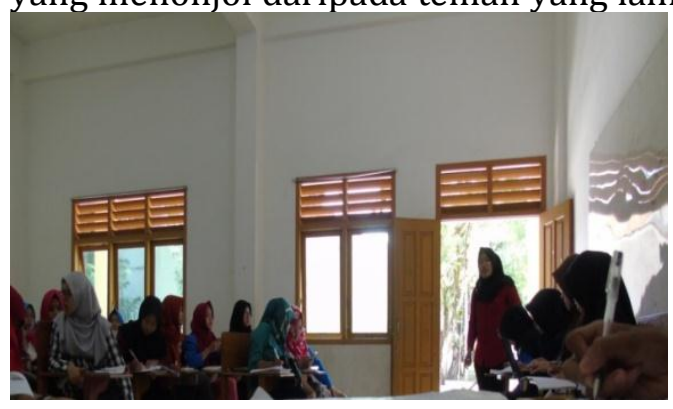

Gambar 5. Pelaksanaan Lesson Study

Pertemuan Keempat

Hasil pertemuan keempat, dosen membuka perkuliahan dengan menyapa mahasiswa dan mengecek kehadiran. Setelah mengecek kehadiran mahasiswa, dosen menanyakan tentang tugas yang diberikan pada pertemuan sebelumnya. Kemudian membahas permasalahan tersebut secara bersama-sama, jika terdapat kesulitan yang tidak dapat diselesaikan oleh mahasiswa, dosen akan menjelaskan atau memberikan solusi dari permasalahan tersebut. Dosen melanjutkan perkuliahan dengan menyampaikan tujuan dari perkuliahan dan membagikan LKM untuk kegiatan perkuliahan. Kegiatan dilanjutkan dengan dosen menampilkan media pembelajaran berupa power point, dan meminta mahasiswa untuk memperhatikan dan memahami apa yang disajikan oleh dosen. Dosen memberikan materi yang dikaitkan dengan kejadian atau yang ada dalam kehidupan sehari-hari. Untuk mengatasi masalah tersebut dosen model mencoba memberikan permasalahan kepada mahasiswa sehingga dapat memberikan dorongan mahasiswa yang masih belum bisa aktif dalam pembelajaran. Ini ditunjukkan juga pada hasil angket self concept yang mereka isi. Pada pertemuan ketiga presentase self concept sebesar 84,21\% dan pertemuan ketiga rata-rata nilai kuis yang dilakukan sebesar 81,34.

\section{c) Refleksi (See)}

Dalam pembelajaran ini penerapan metode ini berjalan dengan baik dan lebih aktif pembelajaran yang dilakukan berjalan lancar tanpa kendala yang berarti. Mayoritas mahasiswa tergolong aktif dan self concept mahasiswa sudah terlihat ketika mereka mengemukakan ide yang ada dan dalam mengikuti pembelajaran tidak ada yang menonjol daripada teman yang lainnya dengan presentase sebesar $84,21 \%$ dan pertemuan ketiga rata-rata nilai kuis yang dilakukan sebesar 81,34.. Ternyata metode yang digunakan pada pertemuan ketiga dan keempat self concept mahasiswa semakin meningkat sehingga indikator dari self concept terpenuhi dibuktikan dengan hasil angket yang telah diisi dan dibantu dengan hasil kuis mahasiswa yang dilakukan diakhir pertemuan dengan materi pertidaksamaan kuadrat.

Berdasarkan tahapan penerapan lesson study yang telah dilakukan terhadap mahasiswa semester I pendidikan sekolah dasar di mata kuliah konsep dasar matematika STKIP PGRI kota Lubuklinggau, diperoleh data berdasarkan observasi dan angket self concept mahasiswa yang menunjukkan peningkatan self concept mahasiswa pada setiap pertemuan yang telah dilakukan. self concept adalah kemampuan untuk siswa dalam memahami dan menempatkan dirinya dalam belajar, khususnya matematika sehingga sebelum belajar siswa diharapkan mampu untuk membuat sebuah konsep dasar matematika [7]. Dapat disimpulkan bahwa self concept adalah keyakinan diri seseorang mengenai dirinya sendiri yang berkaitan dengan pengetahuannya tentang apa yang diketahuinya tentang matematika, harapan siswa tentang pembelajaran matematika yang ideal dan penilaian siswa terhadap matematika.

Lesson study adalah bentuk kegiatan yang dilakukan oleh seorang guru/sekelompok guru yang bekerja sama dengan orang lain (dosen, guru) dalam merancang kegiatan untuk meningkatkan mutu belajar siswa dan pembelajaran yang dilakukan oleh seorang guru dari perencanaan pembelajaran yang dirancang bersama/sendiri, kemudian diobservasi oleh teman guru yang lain san setelah itu melakuakn refleksi bersama atas hasil pengamatan yang baru saja dilakukan. [3]

Jika dihubungkan dengan hasil penelitian dapat diketahui bahwa lesson study dapat meningkatkan self concept mahasiswa. Subjek penelitian ini memiliki kecenderungan menyukai pilihan jawaban yang lebih dominan pada salah satu indikator dibandingkan pengukuran lainnya. Dibuktikan dari analisis deskriptif 30 indikator dalam mengukur self concept. Pada pertemuan pertama presentase sebesar 67,96\%, di pertemuan sebesar kedua 70,67\%, di pertemuan ketiga sebesar 81,85\%, dan di pertemuan keempat sebesar 84,21\%. Setelah perhitungan persentase jawaban responden terhadap aspek-aspek pada angket self concept mahasiswa dapat disimpulkan bahwa self concept mahasiswa mengalami peningkatan pada setiap pertemuan. 
Perbandingan persentase jawaban responden mahasiswa terhadap aspek self concept dapat dilihat pada grafik di bawah ini:

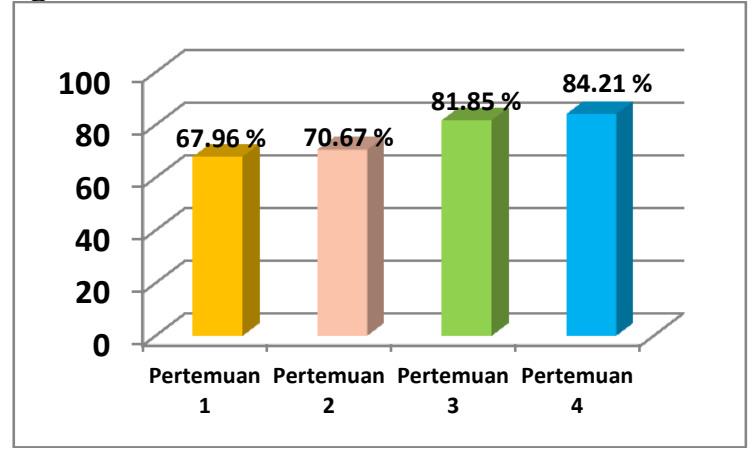

Gambar 6. Persentase Jawaban Responden Terhadap Aspek Self Concept

Dibuktikan pula dengan hasil kuis yang dilakukan pada setiap akhir pertemuan, pada pertemuan pertama rata-rata sebesar 73,76 , pada pertemuan kedua rata-rata sebesar 74,47 , pada pertemuan ketiga rata-rata sebesar 77,73 , dan pada pertemuan keempat rata-rata sebesar 81,34 . Setelah perhitungan jawaban responden kuis yang diberikan kepada mahasiswa dapat disimpulkan bahwa mahasiswa mengalami peningkatan pada setiap pertemuan. Perbandingan persentase jawaban responden mahasiswa terhadap kuis yang diberikan dapat dilihat pada grafik di bawah ini:

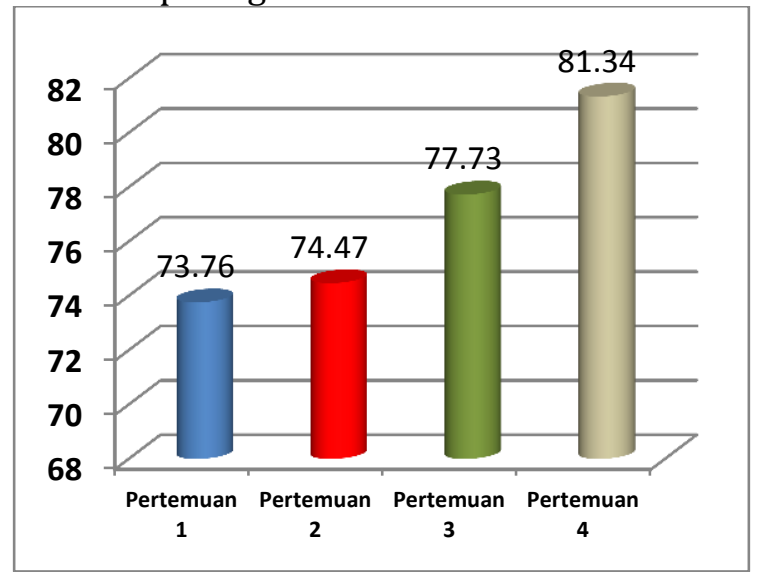

Gambar 7. Rata-rata Jawaban Kuis Mahasiswa

Hal ini kemungkinan mahasiswa dalam mengisi angket tidak bersungguh-sungguh dikarenakan adanya rasa takut pengisian angket, adanya rasa malas membaca dalam pengisian angket dan adanya rasa tidak ketertarikan dalam pengisian angket. Padahal sebelum angket disebarkan, mahasiswa telah diberi penjelasan oleh dosen kalau angket ini tidak mempengaruhi terhadap nilai mahasiswa.

\section{SIMPULAN DAN SARAN}

\section{Simpulan}

Self Concept mahasiswa yang tumbuh dapat terlihat dari modalitas belajarnya tumbuh dari setiap pertemuan yang dilakukan, sehingga mengakibatkan kesiapan pelibatan dalam pembelajaran semakin baik. Peningkatan self concept dari pertemuan pertama ke pertemuan kedua sebesar 2,71\%. Peningkatan self concept dari pertemuan kedua ke pertemuan ketiga sebesar 11,18\%. Peningkatan self concept dari pertemuan pertemuan ketiga ke pertemuan keempat sebesar 2,36\%. Peningkatan self concept secara keseluruhan dari pertemuan pertama ke pertemuan keempat sebesar 16,25\%. Dibuktikan pula dengan hasil kuis yang dilakukan pada setiap akhir pertemuan, pada pertemuan pertama ke pertemuan kedua peningkatannya diambil dari rata-rata sebesar 0,71. Pada pertemuan kedua ke pertemuan ketiga peningkatannya diambil dari rata-rata sebesar pada pertemuan kedua rata-rata sebesar 3,26. Peningkatan secara keseluruhan temuan lain pada rata-rata kuis mahasiswa peningkatan terjadi sebesar 7,28.

\section{Saran}

Dari hasil pembelajaran berbasis Lesson Study ini dapat diberikan saran Lesson Study dapat dijadikan sebagai sarana untuk meningkatkan dan mengembangkan kualitas pembelajaran di Perguruan Tinggi. Rencana Pelaksanaan Pembelajaran (RPP) sebaiknya dibuat secara teperinci sehingga orang lain benar-benar bisa melihat gambaran yang akan dilakukan oleh dosen model dalam kelas. Pengukuran indikatorindikator pelaksanaan Lesson Study sebaiknya juga dirancang secara kuantitatif agar memberikan hasil yang lebih mudah untuk diinterpretasikan kedepannya.

\section{UCAPAN TERIMA KASIH}

Kami ucapkan terima kasih kepada pihak-pihak yang telah berkontribusi dalam penulisan artikel ini. Kepada bapak Dr. Saleh Haji, M.Pd selaku pembimbing yang telah membimbing mulai dari awal sampai akhir dalam penulisan artikel ini. Terkhusus kepada Prodi S2 Pendidikan Matematika Universitas Bengkulu dan Prodi S1 Pendidikan Matematika STKIP Lubuklinggau.

\section{REFERENSI}

[1] Dwi siswoyo, dkk. (2008). Ilmu Pendidikan. Yogyakarta: UNY Press.

[2] Fachruddin. (2010). Penerapan Lesson Study di JPMIPA FKIP Universitas Bengkulu (Adaptasi dari Pengalaman IMSTEP-JICA). Universitas Bengkulu.

[3] Haji, S. (2014). Meningkatkan Kualitas Pembelajaran Teori Bilangan Melalui Lesson Study. Retrieved from http://repository.unib.ac.id/7154/

[4] Lestari, K.E \& Yudhanegara, M.R. (2015). Penelitian Pendidikan Matematika. Bandung : PT Refika Aditama.

[5] Shirley Harison. (2001). Media Relations: Konsep, Pendekatan dan Praktik. Bandung : PT. Rosdakarya.

[6] Sumartini, T. S. (2014). Penerapan Model Pembelajaran Concept Attainment Untuk Meningkatkan Kemampuan 
Penalaran Matematis Dan Self Concept Siswa Smp: Studi Kuasi Eksperimen Pada Kelas VIII di Salah Satu SMP Negeri Tarogong Kaler Garut(Doctoral dissertation, Universitas Pendidikan Indonesia). Retrieved from http://repository.upi.edu/15582/

[7] Wahyudi, Imam. (2012). Pengembangan pendidikan : Strategi Inovatif dan Kreatif dalam Mengelola Pendidikan Secara Komprehensif. Jakarta: Prestasi Pustakaraya. 